\title{
REVIEW OF PAN-CANADIAN GLOBAL COMPETENCIES IN THE CONTEXT OF THE REFORMING OF PRIMARY EDUCATION IN UKRAINE
}

\author{
Antonina Shturba ${ }^{1}$ \\ ${ }^{1}$ Post-graduate student, Department of Pedagogy, Uman State Pedagogical University named after Pavlo \\ Tychyna, English teacher of the Municipal establishment «Balta pedagogical professional college», Uman, \\ Ukraine, e-mail: shturba.antonina85@gmail.com,ORCID: https://orcid.org/0000-0002-1983-7332
}

\begin{abstract}
This article focuses on education reform and modernization in Ukraine, as well as Canadian educational experience in defining global competencies. The school becomes the place where the key competencies necessary for further life and self-development should be formed. Among these core competencies, the Council of Ministers of Education of Canada identifies critical thinking, lifelong learning, communication, collaboration, creativity, entrepreneurship, and more. In the context of reforming education in Ukraine, the Concept of the New Ukrainian School also prescribes the key competencies that a future citizen, patriot and innovator of their country should possess. In a modern primary school, the child's focus is not on the accumulation of information, but on the assimilation of intellectual techniques that are part of the culture and an integral part of the content of education. The main thing in education should be interest, development of cognitive activity of junior schoolchildren, formation their positive attitude to process and results of the work. The article contains a comparative analysis of two groups of competencies: Pan-Canadian global competencies and key competencies of the New Ukrainian School. In addition, some aspects of the successful implementation of competency-based learning are presented, the features of the pedagogy of partnership and inclusive learning are considered. Indeed, generations of children come to school living in an information society, in a digital environment, and to reap its benefits, we educators need to rethink the value of knowledge and the self-sufficiency of the teacher as a source of information. The main mission of the school is to bring the student's personality into a mode of self-improvement through the formation of key competencies.
\end{abstract}

Keywords: global competencies, competency-based learning, primary education, educational reforming, critical thinking, lifelong learning.

JEL Classification: I24, 29

Formulas: 0; fig.: 0; tabl.: 0; bibl.: 13

Introduction. In the modern world the problem of creative development of the person is acute. Every civilized country cares about the creative potential of society in general and each person in particular. Increased attention to the development of creative abilities of the individual, giving him the opportunity to identify them. Therefore, the formation of key competencies of students is relevant today. This problem is the purpose of modernizing the content of education.

Modern society requires the education of independent, proactive, responsible citizens who are able to effectively interact in the performance of social, industrial and economic tasks. The urgent task of the modern school is the implementation of a competency-based approach to learning, which involves the focus of the educational process on the formation and development of key competencies of the individual.

Literature Review. The Council of Ministers of Education of Canada (2017a) presented global competencies which are based on strong foundation of mathematical and language literacy and were designed to prepare students for an unpredictable and complex future with rapidly changing social, economic, political, environmental and 
technological living conditions [2]. 21st century education is human education. It is based on the education of a responsible person who is capable of self-education and self-development, who is able to use the acquired knowledge and skills to creatively solve problems, think critically, process a variety of information, seeks to change their lives and the lives of their country [12, p.180]. Radical changes and innovations are taking place in the system of primary education in Ukraine. Ukrainian firstgraders from September 1, 2018 study according to the new State Standard of Primary Education approved by the Cabinet of Ministers of February 21, 2018 № 87. The standard was developed as part of the reform «New Ukrainian School» in accordance with the Law of Ukraine «On Education» and defines basic requirements for primary education in the country. Skyba M. notes that the New Ukrainian School works on the basis of partnership pedagogy, which is based on communication, interaction and cooperation between teacher, student and parents. Students, parents and teachers, united by common goals and aspirations, are voluntary and interested like-minded people, equal participants in the educational process, responsible for the result [13].

Aims. The main aim is to demonstrate the Canadian educational experience in defining global competencies and compare them with the key competencies prescribed in the Concept of the New Ukrainian School.

Methods. In order to enrich the theoretical knowledge designed to improve the process of education, upbringing and development of children, we used theoretical methods of analysis, comparison and generalization of the achievements of Canada and Ukraine in the formation of global competencies in the context of modernizing education.

Competence is the ability to apply the acquired knowledge, skills, abilities, methods of activity, own experience in non-standard situations in order to solve certain vital problems. Competence is a personal formation, which is manifested in the process of active independent human action.

The introduction of a competency-based approach to education involves reforming education in the following main areas:

- clarification of the purpose (goals) of training;

- improving the content of education;

- updating the educational and methodological support of the educational process (creation of new textbooks, manuals, didactic material, multimedia tools, etc.);

- selection of effective methods, teaching methods and forms of organization of educational activities;

- teacher preparation for the implementation of the competence approach in teaching.

One of the ways to update the content of education and harmonize it with the problems of today is the orientation of the educational process on the formation of key competencies and the creation of effective mechanisms for their application. Of great importance in this matter for Ukraine is the experience of foreign countries that have achieved significant success in updating the content of education in accordance with today's requirements and have high educational performance in the world. 
Results. The primary level of education is the foundation of schooling, because this is where the foundation for the formation of the personality of the future citizen is laid. It is designed to ensure the further formation and comprehensive development of the child, purposefully identify and develop its abilities in various activities, create conditions for the full mastery of the basic level of education and the ability to learn throughout life [12, p.180-181].

To implement competency-based learning in modern schools, which aims to educate the world's citizen with an active life position, it is important to study the positive experience of countries that have achieved significant success in updating the educational process of primary school in accordance with today's requirements.

Competence approach in education is designed to bridge the gap between education and life. In order to form in students the ability to learn, to master knowledge rationally, it is important to develop in them a whole set of various organizational and intellectual skills that are provided with independence in learning.

The New Ukrainian School (NUS) is a key reform of the Ministry of Education and Science. The main goal is to create a school in which it will be pleasant to study and which will give students not only knowledge of how it is happening now, but also the ability to apply them in everyday life. The main principles of school education reform and the approximate schedule for the implementation of the reform are set out in the Concept of the New Ukrainian School where we find «five areas that were most broadly discussed and require further refinement and reconciliation:

1. Pedagogy of partnership.

2. Readiness for innovation.

3. New standards and learning outcomes.

4. The school and teacher autonomy.

5. Education funding» [6, p.2-3].

Discussion. The Council of Ministers of Education, Canada (CMEC) is an intergovernmental body established in 1967 by ministers of education working on a variety of activities, projects and initiatives.

At the 105th CMEC meeting in 2016, the ministers of education represented six broad competencies. They are:

Critical thinking and problem solving - refer to addressing complex issues and problems by acquiring, processing, analyzing, and interpreting information to make informed judgments and decisions.

Innovation, creativity, and entrepreneurship — involve the ability to turn ideas into action to meet the needs of a community.

Learning to learn and to be self-aware and self-directed - means becoming aware of and demonstrating agency in one's process of learning, including the development of dispositions that support motivation, perseverance, resilience, and self-regulation.

Collaboration - involves the interplay of the cognitive (including thinking and reasoning), interpersonal, and intrapersonal competencies necessary to participate effectively and ethically in teams. 
Communication - involves receiving and expressing meaning (e.g., reading and writing, viewing and creating, listening and speaking) in different contexts and with different audiences and purposes.

Global citizenship and sustainability - involve reflecting on diverse world views and perspectives and understanding and addressing ecological, social, and economic issues that are crucial to living in a contemporary, connected, interdependent, and sustainable world [2, p.4-5].

Compared to the classification and definitions of global competencies of Canadian researchers, the Concept of the New Ukrainian School gives us slightly different classification and definition of 10 key competencies of the New Ukrainian School:

Communication in the national language (and mother tongue, if different). The ability, in speech and writing, to express and interpret ideas, thoughts, feelings, facts and views: by listening, speaking, reading, writing, and the use of multimedia.

Communication in foreign languages. The ability to understand adequately concepts expressed in a foreign language, to express both in speech and in writing the ideas, thoughts, feelings, facts and views.

Mathematical literacy. A culture of logical and algorithmic thinking. The ability to use mathematical (numerical and geometrical) methods to solve practical tasks in various areas of activity.

Competencies in Science and Technology. The ability to apply scientific methods to observe, analyze, formulate hypotheses, collect data, conduct experiments and analyze their results.

ICT and digital competencies envisage confidence and critical appraisal in the use of Information and Communication Technology (ICT) to produce, research, process and exchange information at the workplace, in the public domain and in personal communication.

Lifelong learning skill. The ability to search and master new knowledge, to gain new skills, to organize an educational process (individually and in groups), in particular, through effective resource and information flow management, an ability to set educational goals and determine means to achieve them, to build one's own educational and professional trajectory, to appraise your own educational achievements, and to learn throughout life.

Sense of entrepreneurship. The ability to generate and bring to life new ideas and initiatives in order to increase both one's own social status and wellbeing, and development of the community and the nation as a whole.

Social and civic competencies. The ability to work with others to achieve results, to prevent and resolve conflicts and reach compromises.

Cultural awareness. The ability to appreciate objects of art, form one's own artistic tastes, independently express ideas, experiences and feelings towards art.

Environmental awareness and healthy lifestyles. The ability to use natural resources in a prudent and rational way within the framework of sustainable development, the realization of the role of the environment in human life and health, and the ability and willingness to live a healthy lifestyle [6, p.11-12]. 
So, we can see that Pan-Canadian global competencies are more general and relate to the more general development of personality, which is realized mainly through integration and interdisciplinary links. As the Council of Ministers of education of Canada declare «there is growing recognition that global competencies promote deeper learning by equipping students with the necessary tools to adapt to diverse situations and become lifelong learners. These key competencies can be interdependent and leveraged in a variety of situations and across disciplines» [2, p.2]. At the same time 10 key competencies for the primary school in Ukraine have a narrower direction. Such competence as «communication» (from Pan-Canadian global competencies) has two branches in Ukrainian classification: communication in the national language and in foreign languages. We suggest that this fact shows different attitudes to the concept of language learning in both countries. In Canada they don't divide the ability to communicate into individual skills to communicate in other languages. Language learning in this country is a common phenomenon, not a time requirement or a curriculum. But in Ukraine we distinguish the ability to communicate in a foreign language in a separate competence because this aspect is problematic and needs more attention from teachers and researchers. We should work a lot to increase the level of learning foreign languages in our country.

If we will speak about «critical thinking and problem solving» (from PanCanadian global competencies), we can generalize that in the New Ukrainian School this competence is displayed in such positions as «competencies in science and technology» and «mathematical literacy». But in Canadian education global competencies are built «on strong foundations of numeracy and literacy» [2, p. 2]. So, in Ukrainian primary education we also must pay more attention to the ability to use mathematical (numerical and geometrical) methods to solve practical tasks in various areas of activity.

Canadian «global citizenship and sustainability» and «collaboration» competencies are partially displayed in Ukrainian «social and civic competencies» which means «constructive participation in society, in the family and at work» and also «the ability to work with others to achieve results, to prevent and resolve conflicts and reach compromises». Therefore, one can again observe a tendency to fragment in the definition of key competencies in Ukrainian education. Collaboration in Ukrainian school is just a part of the lesson as some kind of team game or exercise. But the same separate competence in Canadian school has broader meaning and application: their students interact with different communities or groups and use a number of technologies suitably to work with others.

According to CMEC Pan-Canadian competence «innovation, creativity and entrepreneurship» gives students the opportunity «to contribute solutions to complex economic, social, and environmental problems or to meet a need in a community in a number of ways including: enhancing concepts, ideas, or products through a creative process, taking risks in their thinking and creating, discovering through inquiry research, and by hypothesizing and experimenting with new strategies or techniques; to demonstrate leadership, initiative, imagination, creativity, spontaneity, and ingenuity in a range of creative processes and motivate others with an ethical 
entrepreneurial spirit; to formulate and express insightful questions and opinions to generate novel ideas» [2, p. 7]. In the NUS there is the competence named «sense of entrepreneurship» which has the aim to teach students to generate new ideas and initiatives in order to increase own social status and development of the community. It gives the ability to behave reasonably and make rational decisions in employment, finance and other areas.

Among Canadian global competencies, we do not find individual subject competencies such as mathematical competence, science and technology competence, information and digital competence, environmental literacy and healthy living. All these concepts are to some extent part of different global competencies. But in Ukraine, for example, environmental literacy is one of the key competencies of NUS.

The only competence that completely coincides in Canadian and Ukrainian education is lifelong learning. This is a requirement of time, without which the modern citizen of the interdependent world will not be able to realize himself as a fully developed person, a skilled worker, a conscious citizen of his country. An integral part of this competence is the development of emotional intelligence to understand yourself and others.

An important factor in the successful implementation of the competency-based approach to learning is the selection of effective methods, techniques and forms of organization of educational activities. Competence-based learning requires the use of methods that involve active student activity: productive (studied material is used in practice); heuristic or partially exploratory (some elements of new knowledge the student finds by solving cognitive problems); problematic (the student is aware of the problem and finds ways to solve it); interactive (active interaction of all students, during which each student comprehends his activity, feels his success).

Conclusion. The modern school as a socio-pedagogical system is designed to ensure the achievement of such educational results that would meet the goals of personal development and modern requirements of society. To live with dignity in modern society, the individual must be competent in various fields. The school should help students to master the technologies of life creation, create conditions for unlocking the potential of self-knowledge, self-esteem, self-realization, integration into the socio-cultural space.

Today dictates to us the fast pace of life, a huge amount of diverse information, the development of science, technology, etc. and very often a small child needs to rethink all this, choose the main, important, weed out the unnecessary, secondary. Therefore, primary school faces important tasks to teach all this to children to have a good end result.

The school teaches the child to competently choose their life path, taking into account their abilities and capabilities, to set themselves the task of selfimprovement, self-development, self-education, self-education. The task of the primary level as an educational process is the comprehensive development of younger students, students gain experience in communication, the formation of their desire and ability to learn. 
The introduction of key competencies in the content of education is due to the need to solve a number of problems, including the inability of students to apply acquired knowledge, skills, abilities and values of orientation in real life situations, to meet society's requirements for knowledge renewal. As well as the ability to adapt to rapid changes in socio-economic conditions, to adapt to changing conditions, to be able to find ways to solve problems that arise in practical, cognitive, communicative and other activities.

The pedagogy of partnership is also very important and indispensable because it helps to create an atmosphere in which the potential of each student is best revealed, his initiative and creativity are formed. And this is one of the key assets of the modern world. The partnership satisfies the need for significance and belonging and reduces stress levels, which ultimately helps the intellect work more efficiently. This format of relationships best prepares young people for professional activities and the role of an active citizen in the open world.

Thus, in the context of modernizing the content of education in Ukraine and reforming primary education, Canada's experience as a country with a high level of education can be a role model. The study of the experience of other countries aims to help build the educational process so that the school is a place where a conscious, active, intelligent, healthy citizen of an interdependent world will grow.

\section{References:}

1. Center of Global Education. (2018). Teaching for Global Competence in a Rapidly Changing World. Retrieved from https://www.oecd-ilibrary.org/docserver/9789264289024-

en.pdf?expires=1609763915\&id=id\&accname=guest\&checksum=9CC715DC9C46CDDD21BDF6C60FCECBC0

2. Council of Ministers of Education, Canada. (2017). Pan-Canadian global competencies: Backgrounder. Retrieved from CMEC Website:

https://www.cmec.ca/Publications/Lists/Publications/Attachments/401/Pan-

Canadian\%20Global\%20Competencies\%20Backgrounder_EN.pdf

3. Council of Ministers of Education, Canada. (2017 b). Pan-Canadian Systems-Level Framework on Global Competencies: Literature Review. Retrieved from CMEC Website

https://www.cmec.ca/Publications/Lists/Publications/Attachments/402/Pan-

Canadian\%20framework\%20on\%20Global\%20Competencies\%20Literature\%20Review EN.pdf

4. Holovina, O. (2019) Chomu inkliuziia - nevidiemna oznaka osvity v Kanadi. [Why inclusion is an integral part of education in Canada]. Retrieved from NUS Website https://nus.org.ua/articles/chomu-inklyuziya-nevid-yemna-oznakaosvity-v-kanadi/ [in Ukrainian].

5. Jackson, A., Schleicher, A. (2018). How to prepare students for the complexity of a global society. Retrieved from https://oecdedutoday.com/how-to-prepare-students-for-the-complexity-of-a-global-society/

6. Kontseptsiia Novoi Ukrainskoi Shkoly. (2016). Retrieved from MON Website

https://mon.gov.ua/storage/app/media/zagalna\%20serednya/nova-ukrainska-shkola-compressed.pdf [in Ukrainian].

7. Ministerstvo osvity i nauky Ukrainy. Nova Ukrainska Shkola. Retrieved from MON Website https://mon.gov.ua/ua/tag/nova-ukrainska-shkola [in Ukrainian].

8. Nova Ukrainska Shkola. (2017). Deputaty zminyly perelik kliuchovykh kompetentnostei NUSH [The New Ukrainian School. Deputies changed the list of key competencies of NUS]. Retrieved from NUS Website https://nus.org.ua/news/deputaty-zminyly-perelik-klyuchovyh-kompetentnostej-nush/ [in Ukrainian].

9. Pavlichenko, T. (2020). Krytyka - tse dobre. Yak poiasnyty ditiam, shcho take krytychne myslennia $i$ yak nym korystuvatys [Criticism is good. How to explain to children what critical thinking is and how to use it]. Retrieved from NUS Website https://nus.org.ua/articles/krytyka-tse-dobre-yak-poyasnyty-dityam-shho-take-krytychne-myslennya-iyak-nym-korystuvatys/ [in Ukrainian].

10. Pometun, O. (2017). Yak rozvyvaty krytychne myslennia v uchniv (z prykladom uroku) [How to develop critical thinking in students (with a sample lesson)]. Retrieved from NUS Website

https://nus.org.ua/articles/krytychne-myslennya-2/ [in Ukrainian].

11. Pro zatverdzhennia Derzhavnoho standartu pochatkovoi osvity. Postanova Kabinetu Ministriv Ukrainy vid 21 liutoho 2018 r., № 87. Retrieved from https://zakon.rada.gov.ua/laws/show/87-2018-\%D0\%BF\#Text [in Ukrainian].

12. Romanchuk, A. (2018) Aktualni problemy reformuvannia pochatkovoi osvity Ukrainy v suchasnykh umovakh [Actual problems of reforming primary education in Ukraine in modern conditions]. Naukovi zapysky [Natsionalnoho 
pedahohichnoho universytetu imeni M. P. Drahomanova]. Seriia: Pedahohichni nauky: [zbirnyk naukovykh statei]. Kyiv: Vydavnytstvo NPU imeni M. P. Drahomanova, CXXXX (140), 180-185. [in Ukrainian].

13. Skyba, M. (2019) Krashche razom. Shcho take pedahohika partnertsva i navishcho vona v NUSh [Better together. What is partnership pedagogy and why is it in NUS]. Retrieved from NUS Website

https://nus.org.ua/articles/pedagogika-partnerstva-shho-tse-take-ta-yak-zrozumity-chy-vona-ye-u-shkoli/ [in Ukrainian].

Received: April 18, 2021

Approved: May 24, 2021 